\title{
Environmental Deterioration and Conservation in Cuban Agriculture ${ }^{1}$
}

José Alvarez ${ }^{2}$

On October 28, 2000, U.S. President Bill Clinton signed the Trade Sanctions Reform and Export Enhancement Act (TSRA) which allowed U.S. firms to sell food and agricultural products to Cuba and other countries. However, the Cuban government did not purchase any of these products until December of 2001 following the devastating damage caused by Hurricane Michelle to important agricultural areas in November of that year.

Cuban purchases from U.S. firms amounted to $\$ 4.319$ million in 2001, \$138.635 million in 2002, and \$256.9 million in 2003. Cuba became the 35th most important food and agricultural export market for the United States in 2003, up from last (226th) in 2000. Actual purchases and pending contracts in the first-half of 2004 are at a pace to move Cuba into the top 20 most important markets of U.S. food and agricultural exports. Furthermore, because current U.S. legislation requires that all Cuban purchases from the United States must be conducted on a cash basis, the lack of credit risk associated with these sales makes Cuba one of the most attractive export markets for U.S. firms.
Anticipating changes in U.S.-Cuba trade relations, the Food and Resource Economics Department at UF/IFAS initiated a research initiative on Cuba in 1990, including a 1993 collaborative agreement with the University of Havana, which has lasted to this day. (Most of the resulting publications can be found at http://www.cubanag.ifas.ufl.edu). We reiterate that our role as investigators is to provide the best available information and analyses from which rational decisions can be made. The reports included in this series intend to address the increasing level of interest in the Cuban market for food and agricultural products among U.S. firms and to assist them in becoming more familiar with that market. The complete list of documents in this series can be found by conducting a topical search for "Cuba" at http://edis.ifas.ufl.edu, or under "Additional Information" at the end of this document.

\section{Introduction}

Increasing environmental concerns throughout the world in the past decades have resulted in the identification of benefits resulting from the adoption of one's political philosophy while blaming the

1. This is EDIS document FE489, a publication of the Department of Food and Resource Economics, Florida Cooperative Extension Service, UF/IFAS, University of Florida, Gainesville, FL. Published July 2004. Please visit the EDIS website at http://edis.ifas.ufl.edu.

The author would like to thank the University Press of Florida (http://www.upf.com) for permission to reproduce material from the book Cuba's Agricultural Sector (Alvarez, 2004).

2. José Alvarez, Professor, Department of Food and Resource Economics, Everglades Research and Education Center, Belle Glade, FL, Florida Cooperative Extension Service, UF/IFAS, University of Florida, Gainesville, FL.

The Institute of Food and Agricultural Sciences is an equal opportunity/affirmative action employer authorized to provide research, educational information and other services only to individuals and institutions that function without regard to race, color, sex, age, handicap, or national origin. For information on obtaining other extension publications, contact your county Cooperative Extension Service office. Florida Cooperative Extension Service/Institute of Food and Agricultural Sciences/University of Florida/Christine Taylor Waddill, Dean. 
damages on the opposing viewpoint. This debate is particularly contentious concerning the extent of environmental damage in capitalist and socialist countries. Goldman, for example, quotes a Soviet official stating that, "the capitalist system by its very essence is incapable of taking radical measures to ensure the efficient conservation of resources" (1970, p. 37). However, writing about the Soviet Union, Feshback and Friendly (1992) concluded that "when historians finally conduct an autopsy of the Soviet Union and Soviet Communism, they may reach the verdict of death by ecocide.... No other great industrial civilization so systematically and so long poisoned its land, air, water, and people. None so loudly proclaiming its efforts to improve public health and protect nature so degraded both" (p. 1). Díaz-Briquets and Pérez-López (1998) concluded that "the theoretical arguments about the incompatibility between socialism and environmental disruption had very little to do with reality" (p. 154). The truth is that both capitalism and socialism, when not properly regulated, contribute to the same negative environmental outcomes. As opposed to several years ago, the literature on environmental concerns has been growing in Cuba and abroad.

Summarizing and contrasting part of that body of knowledge is the main objective of this fact sheet. A brief description of Cuba's main physical features introduces the topic (Blutstein et al., 1971; Alvarez, 1994), followed by the evolution of Cuba's environmental legal system. The last sections contain a description of some of the features of environmental deterioration and conservation in Cuban agriculture.

\section{Main Physical and Climatic Features}

The Cuban Archipelago consists of the Isle of Cuba, the Isle of Youth, and about 1,600 small islands and keys that form four major archipelagos (CEE, 1989, p. 19). The mainland of Cuba has an overall length of about 1,200 kilometers from Cape San Antonio in the west to Cape Maisí in the east. Its average width is about 97 kilometers, narrowing to 35 kilometers in the west and widening to 200 kilometers in the east. Its coastline is about 3,500 kilometers long. Water backing up into former valleys and riverbeds have formed numerous fine harbors and bays, but much of the submerged land is capped by coral reefs that present a great hazard to navigation (Blutstein et al., 1971, pp. 9, 10).

Most of the country's terrain is level or rolling. Because there are few mountainous areas to complicate rainfall and temperature patterns, climatic conditions are remarkably similar throughout the country. Most of its rivers are short and are important primarily as sources of water. Rich and generally well-drained soils, a rolling terrain, and wet-dry patterns of moderate rainfall provide nearly ideal growing conditions for many crops (Blutstein et al., 1971, pp. 9, 10).

For the most part, Cuban soils are fertile, but only a few soil types occur over extensive areas. Red clay covers much of the plain in the western region, in Matanza, and in Camaguiey and is most suitable for sugarcane production. Sandy soils, such as the ones in the central plain of Camaguiey, are poor for crops unless abundantly fertilized but support grasses for cattle. The mixed agriculture found around Holguín is the result of the varied soil types in that region. Sandy clays are found in the western region and make the best oils for tobacco. Heavy gray clay comprises most of the watershed of the Cauto River and is good for sugarcane. In the mountainous areas, very fertile soils are found in the river valleys. In the plain of Manacas, north of Cienfuegos, the very poor sandy soils hold very little water and the vegetation is of a drought-resistant type. In the mountains of Pinar del Río, the Isle of Youth, and the Sierra de Nipe, the soil is thin and poor (containing sand, gravel, and limonite) but is well suited for pine trees (Blutstein et al., 1971, p. 17).

Its location and surrounding waters give Cuba a moderate and stable climate. Cuba receives less rain than most other areas in the same latitude. Cuba's rainfall averaged 1,113 millimeters, 1,306 millimeters, and 1,495 millimeters in 2000, 2001 and 2002, respectively. By province, Las Tunas had the least rainfall (912 millimeters) while Sancti Spíritus received the most rainfall (2,219 millimeters) in 2002. The country receives rain one-third of the year (averaged 121 days in 2002). Weather stations reporting the most rainfall and rainy days are generally located on the top of mountains (CEE, 
2002, pp. 17, 18). Cuba has two distinctive seasons based on rainfall. The rainy season lasts from May through October, with almost daily afternoon downpours, especially inland. The dry season lasts from November through April. Temperatures in the country do not show wide variations. Annual mean temperatures range between 24 degrees Celsius $\left(24^{\circ} \mathrm{C}\right)$ and 27 degrees Celsius $\left(27^{\circ} \mathrm{C}\right)$. Although the probabilities of extreme temperatures are very low, a certain number of cold fronts hit the island from time to time and are stronger from November through March, mostly in the western region of the country.

\section{Cuba's Environmental Legal Framework}

Cuba has a comprehensive system of laws and regulations intended to enhance environmental protection and to hinder environmental degradation. Legislation that relates to agriculture includes:

- Law No. 239 which was enacted right after the revolution in 1959. This law, entitled "Ley de Repoblación Forestal" (Law of reforestation), had the objective of starting the development of a national reforestation program (Pichs, 1992).

- Article 27 of Cuba's 1976 Constitution contains a brief provision about the protection of nature by the state and every citizen (Constitución, 1995, p. 16). The 1992 amendments to the Constitution expanded Article 27 to include the concept of sustainable development. It also proclaimed the sovereignty of the state over the nation's environment and natural resources and it designated the provincial and municipal assemblies of People's Power as the official enforcers (Constitución, 1996, pp. 7-8, 17, 55, 58).

- Law No. 33, "De la Protección del Medio Ambiente y del Uso Racional de los Recursos Naturales" (On the Protection of the Environment and the Rational Use of Natural Resources), was enacted in December of 1980 and took effect in January of 1981. It established a national system, composed of various organizations and enterprises, to foster the stewardship of the environment. The law also states the sanctions that are to be imposed against violators (Barba and Avella, 1995; Díaz-Briquets and Pérez-López, 2000, pp. 49-53).

- Decree-Law No. 118, "On the Structure, Organization, and Operation of the National System for the Protection of the Environment and the Rational Use of Natural Resources," was approved by the Council of State on January 18, 1990. It created the National Commission for the Protection of the Environment and the Rational Use of Natural Resources (COMARNA). A series of complementary decrees by the Council of Ministers and regulations issued by governmental agencies were later developed (Díaz-Briquets and Pérez-López, 2000, pp. 53-59).

- Law No. 81, "Law on the Environment," was passed by the National Assembly of People's Power on July 11, 1997. It is the main legal framework for environmental protection. It superseded Law No. 33 (in effect since 1981) and Decree Law No. 118 (in effect since 1990). It consists of a preamble and 14 titles containing 163 articles, special provisions, transitory provisions, and final provisions. COMARNA was absorbed by the newly created Ministry of Science, Technology, and the Environment (CITMA), formerly Cuba's Academy of Sciences, which is in charge of developing and implementing environmental policy. The importance of this law rests on its in-depth description of the sources of pollution and the penalties imposed on polluters, the requirement to acquire an environmental license for an activity that is likely to affect the environment, the enforcement of an environmental impact assessment, and an emphasis on education (Díaz-Briquets and Pérez-López, 2000, pp. 65-67).

- Ratification by the Cuban government of numerous international environmental agreements places them at the same level as domestic laws.

In terms of identifying responsibilities, before implementing Cuba's environmental legal system, Rey Santos (1996) wrote an extensive article in 
which he studied each transgression of the laws and regulations to determine responsibilities and penalties. Díaz-Briquets and Pérez-López, however, state that, "because Cuba's environmental laws are general, they are difficult to enforce.

Moreover, environmental protection institutions are weak, and their ability to enforce laws and regulations is severely limited by their lack of authority to interfere in matters under the control of economic-sector ministries. To date, the role of environmental protection institutions has been that of motivators and coordinators rather than enforcers" (2000, pp. 46-47). In effect, a cursory review of the literature revealed just one case of applying the laws. The U.S.-Cuba Trade and Economic Council reported that the Cuban government had imposed a fine of 287,000 Cuban pesos (about US\$14,000) on the government-operated Melanio Hernández sugar mill in Sancti Spíritus, located 350 kilometers east of Havana. The fine was assessed because the mill was discharging pollutants into the Tuinicú river, which in turn entered the Zaza dam reservoir, causing the death of 1,000 tons of fish and other unspecified ecological damage (USCTEC, 1998, p. 3).

\section{Some Features of Environmental Deterioration}

This section summarizes documented instances of environmental deterioration in the agricultural sector. A plausible explanation of a relationship between environmental behavior and type of agricultural organization is also examined. Finally, the impact of the Special Period in Time of Peace is briefly discussed.

\section{Agriculture in General}

There exist numerous accounts of environmental deterioration in Cuba's agricultural sector. The following list mentions the most striking examples:

- Soil Erosion: In addition to natural phenomena (rains, rivers, and winds), modern agricultural practices can contribute significantly to soil erosion. In Cuba, the problem accelerated in the 1980s with the implementation of the state extensive growth model in agriculture. COMARNA (1991, pp. 11-12) has estimated that 7,711,500 hectares out of a total land area of $11,016,400$ hectares, or $70 \%$, are affected by some degree of erosion (Espino, 1992, p. 330). Although erosion is more evident in the mountains, it is also considerable in Cuba's most fertile and relatively flat regions (Díaz-Briquets and Pérez-López, 2000, p. 92).

- Soil Compaction: This may be the result of the physical properties of the soil, but the use of machinery and equipment is also an important contributor. The tremendous increase in the use of heavy machinery and equipment during the implementation of the extensive growth model has been documented (Alvarez and Messina, 1992). According to COMARNA (1991, p. 15), soil compaction affects 1.6 million hectares of agricultural land in Cuba (Sáez, 1997c, p. 45).

- Soil Salinity and Acidity: Excessive irrigation may produce or aggravate soil salinity, as may inadequate irrigation and excessive use of fertilizers. COMARNA (1991, pp. 11-12) reports that $10 \%$ of Cuba's total surface area is affected by salinization (Espino, 1992, p. 330). Some specialists put that figure at $32 \%$ of agricultural land (Sáez, 1997c, p. 46). COMARNA (1991, p. 53) meanwhile reports land affected by acidification at $28.5 \%$ of all agricultural land, or 1,772,662 hectares (Sáez, 1997c, p. 47).

- Water Resources: The supply of water for the agricultural sector has always been a priority of the Cuban government. The establishment of the National Institute of Hydraulic Resources (INRH), as early as 1962, reflects Castro's objective that "not a single drop of water be lost, that not a drop of water reach the sea ... that not a single stream or river not be dammed" (El Paisaje, 1982, p. 52). An ambitious dam construction program and an increase in the extraction rate of underground water have resulted in the contamination of a considerable volume of water in aquifers and increased salinization from salt water intrusion near coastal areas (Díaz-Briquets and Pérez-López, 2000). Furthermore, agricultural and animal production in 1989 was generating around nine million tons of solid residues and about 27 million cubic meters of liquid residues 
per year (Atienza Ambou et al., 1992, p. 13). In addition to the increase of a waste disposal problem, contamination of waters have intensified.

Another agricultural environmental problem is the damage inflicted to mangroves (26\% of total forest resources) due to over-exploitation (COMARNA, 1991, p. 9).

\section{Relationship with Type of Ownership}

The list of examples of environmental degradation in socialist Cuba from the previous section demands further consideration. In addition to the policies inherent to a socialist system, work by Sáez (1997a; 1997b) adds considerably to the information developed in the last few years on resource conservation and degradation in Cuba. They are also important because they are the result of field research conducted by the author, then a foreign graduate student. From the wide range of topics covered by Sáez, this section focuses on the differences in productivity between the state and nonstate sectors.

After presenting data on increasing private sector output in contrast with declining trends in state farms during the Special Period, Sáez (1997a) asks the following question: "How can private farmers maintain and increase production in the face of widespread chemical-input scarcities?" And he continues, "the evidence presented ... shows that, in the case of Santo Domingo [a rual community in Villa Clara province], private family farmers have conserved and developed their natural resource base, which allowed them to respond to the economic crisis. On the other hand, the state failed to foster resource conservation. The decline of output in state farms is explained in part by the degradation of natural resources in the area" (p. 130).

Sáez's works contain a long list of examples on the trade-offs between production and conservation practices in state farms ("Conservation is not a priority, but maximizing output is.") State managers choose cultural practices that increase production (MINAGRI's main objective), not practices that conserve resources. It is like reading René Dumont's account of the continuous mistakes made in the early years of the revolution. Sáez also enumerates the procedures used by nonstate farmers for resource conservation.

Given the higher productivity achieved by nonstate farmers ("all individual producers interviewed argued that small, individual farming is more productive than state farming in Santo Domingo"), due in part to crop rotation, selective use of organic and commercial fertilizers, intercropping, fallow periods, and many other easy practices, one wonders about the current state of affairs after the establishment of the Basic Units of Cooperative Production (UBPCs). Since the bulk of Saez's research was conducted before their creation, it would be interesting to know the UBPCs' approach to resource conservation-an attractive topic for further research.

In closing this discussion about Sáez's finding of a relationship between stewardship of the environment and type of agricultural organization in Cuba, one final fact deserves mention. A previous section of this fact sheet discussed some of the laws and regulations enacted by the Cuban government to protect the environment. According to Sáez, however, those related to agricultural production and several others are not enforced in the municipality of Santo Domingo. Private farmers in the study area, however, voluntarily apply environmental-conserving practices in their operations.

\section{The Special Period in Time of Peace}

While the establishment of the Special Period in September of 1990 has fostered environmental conservation in some areas, it also has resulted in increases in environmental deterioration in other areas of the agricultural sector. Let us summarize some of these negative effects:

- The reduction in several areas of Cuba's budget for environmental research. This includes the threat to the preservation and maintenance of its scientific collections and to the curtailing of scientific training.

- The damage to marine resources through increased mining and petroleum exploration and 
the indiscriminate construction of new tourist facilities (Cole and Domínguez, 1995, pp. 4-5).

- The damage to forest resources and soil erosion caused by increased demand for firewood and charcoal because of shortages in commercial fuels for home cooking (Espino, 1992, p. 331).

- Contamination from chemical pesticides and dangerous biological agents being used in agriculture (Díaz-Briquets and Pérez-López, 1995, p. 286) .

\section{Some Features of Environmental Conservation}

In addition to environmental degradation, there are several areas of agriculture where conservation has prevailed. This section describes some of the conservation programs and deals with the practices of sustainable agriculture brought about by the Special Period.

\section{Agriculture in General}

The most striking examples of environmental conservation include:

- According to COMARNA (1991, p. 20), recovery of forest areas has been accomplished through an aggressive reforestation effort started in the late 1970s. Since the early 1990s, 110,000 hectares are being replanted every year (Espino, 1992, p. 331). Díaz-Briquets and

Pérez-López state that socialist Cuba has "reversed a deforestation trend that had plagued the country throughout its modern history" (2000, p. 21).

- Cuba has decreased its population growth considerably to well below $1 \%$ per year and is rapidly approaching stabilization if not population size decline (Díaz-Briquets and Pérez-López, 2000, p. 21). This phenomenon has implications for agriculture and conservation since a lower population density in the countryside will translate into less environmental damage.
- Perhaps most importantly, efforts have been conducted in the area of low-input sustainable agriculture. Due to the end of the Soviet subsidies, Cuba was forced to implement national-scale organic farming techniques which had only been tried on a limited basis in the West (Carney and Haynes, 1993, p. 1).

\section{Sustainable Agriculture}

This issue has attracted the attention of Cuban scholars and technicians who have written extensively on general guidelines or specific analyses or projects. Many measures have been taken and farming practices adopted that can be classified as leading toward more sustainable agriculture. Whether they are permanent or transitory remains to be seen. Nevertheless, some of those practices include:

- The implementation of an "alternative" agricultural model, including organic fertilizers; biological pest control; adjusting crops and their husbandry to local ecological conditions; animal traction and other forms of alternative energy; crop diversification and mixed cropping; more input by local labor and community decisionmaking; soil conservation, reclamation of degraded lands, and reforestation; examining local knowledge as a basis for cutting edge and alternative technologies; and reversing rural-to-urban migration to increase the number of Cubans engaged in farming (Vandermeer et al., 1993, p. 5).

- The establishment and development of urban agriculture to help alleviate food scarcity problem. It is comprised of popular gardens, organopónicos and intensive gardens, self-provisioning gardens, private farms, and state enterprises (Grupo Provincial Agropecuario, 1998).

\section{Epilogue}

Romeu (1997, pp. 25-26) describes very vividly, in beautiful terms, what Christopher Colombus must have seen on October 28, 1492, when he called the recently-discovered island of Cuba "the most beautiful land human eyes have ever seen." After describing some exclusive characteristics of Cuba's 
flora and fauna, her final words reflect both her concern and her hope:

As in other parts of the world, all these living wonders have been subject to destruction of the habitats, pollution, hunting, mismanagement as resources, lack of knowledge about nature, caprice of leaders... Some advantages they have had, and one of the most important ones is the present existence of a great deal of professionals in the country: biologists, geographers, ecologists... with good education, sensibility and evaluation of the necessity to protect the natural national patrimony, who have fought during years to preserve what they recognize as valuable and exclusive.

\section{References}

Alvarez, José. 2004. Cuba's Agricultural Sector. Gainesville, FL: University Press of Florida.

Alvarez, José. 1994. Cuba's Infrastructure Profile. International Working Paper IW94-4, Agricultural Trade and Policy Center, Department of Food and Resource Economics, University of Florida, Gainesville, FL (July).

Alvarez, José, and William A. Messina, Jr. 1992. Potential Exports of Florida Agricultural Inputs to Cuba: Fertilizers, Pesticide, Animal Feed and Machinery. International Working Paper IW92Agricultural Trade and Policy Center, Department of Food and Resource Economics, University of Florida, Gainesville, FL (December).

Atienza Ambou, Aida, Anicia García Alvarez, and Oscar U. Echevarría Vallejo. 1992.

Repercusiones Medioambientales de las Tendencias de Desarrollo Socioeconómico en Cuba. Ciudad de la Habana: Instituto Nacional de Investigaciones Económicas.

Barba, B. Ralph and Amparo E. Avella. 1995. Cuba's Environmental Law. Cuba in Transition 5: 276-280.

Blutstein, Howard I., Lynne Cox Anderson, Elinor C. Betters, Deborah Lane, Jonathan A. Leonard, and Charles Townsend. 1971. Area
Handbook for Cuba. Washington, DC: The American University.

Carney, Judith A., and Richard Haynes. 1993. From the Editors. Agriculture and Human Values 10 (3, Summer): 1-2.

CEE. Comité Estatal de Estadísticas. Annual Issues. Anuario Estadístico de Cuba. La Habana: Editorial Estadística.

Cole, Sally, and Jorge I. Domínguez. 1995. U.S.-Cuba Environmental Cooperation: Shared Interests, Problems, and Opportunities. In The Environment in U.S.-Cuban Relations: Opportunities for Cooperation, edited by Inter-American Dialogue, pp. 1-8. Washington, DC: Inter-American Dialogue.

COMARNA. 1991. Informe Nacional a la Conferencia de Naciones Unidas Sobre Medio Ambiente y Desarrollo, Brasil 1992: Sumario Ejecutivo. La Habana.

Constitución de la República de Cuba, 1976. 1995. La Habana: Editorial de Ciencias Sociales.

Constitución de la República de Cuba-Actualizada Según la Ley de Reforma Constitucional Aprobada el 12 de Julio de 1992. 1996. La Habana: Editorial de Ciencias Sociales.

Díaz-Briquets, Sergio, and Jorge Pérez-López. 1995. The Special Period and the Environment. Cuba in Transition 5: 281-292.

Díaz-Briquets, Sergio, and Jorge Pérez-López. 1998. Socialism and Environmental Disruption: Implications for Cuba. Cuba in Transition 8: $154-172$.

Díaz-Briquets, Sergio, and Jorge Pérez-López. 2000. Conquering Nature-The Environmental Legacy of Socialism in Cuba. Pittsburgh, PA: University of Pittsburgh Press.

El Paisaje se Transforma. 1982. Voluntad Hidráulica 19: 52-58.

Espino, María Dolores. 1992. Environmental Deterioration and Protection in Socialist Cuba. Cuba in Transition 2: 327-342. 
Feshback, Murray, and Alfred Friendly, Jr. 1992. Ecocide in the USSR. New York, NY: Basic Books.

Goldman, Marshall I. 1970. The Convergence of Environmental Disruption. Science 170 (October): $37-42$.

Grupo Provincial Agropecuario. 1998.

Temáticas y Perfiles. Ciudad de la Habana: Secretaría de Colaboración.

Pichs, Ramón. 1992. Cuba Ante los Desafíos Ambientales Globales. Centro de Investigaciones de la Economía Mundial, La Habana.

Rey Santos, Orlando. 1996. La Responsabilidad por el Daño Ambiental en Cuba. In $L a$ Responsabilidad por el Daño Ambiental, edited by PNUMA. Serie de Documentos Sobre Derecho Ambiental No. 5, Programa de las Naciones Unidas para el Medio Ambiente, Oficina Regional para América Latina y el Caribe, Mexico, DF.

Romeu, Emma. 1997. Los Dioses Tosen (Reportajes de Medio Ambiente) Mexico-Cuba: 1986-1997, Morelia, Michoacán, Mexico: Instituto Michoacano de Cultura, Universidad de Guadalajara.

Sáez, Héctor R. 1997a. Property Regimes, Technology, and Environmental Degradation in Cuban Agriculture. Ph.D. Dissertation, University of Massachusetts, Cambridge, MA (May).

Sáez, Héctor R. 1997b. Property Rights, Technology, and Land Degradation: A Case Study of Santo Domingo, Cuba. Cuba in Transition 7: 472-485.

Sáez, Héctor R. 1997c. Resource Degradation, Agricultural Policies, and Conservation in Cuba. Cuban Studies 27: 40-67.

USCTEC. U.S.-Cuba Trade and Economic Council. 1998. Economic Eye on Cuba, September 14 to September 20, p. 3.

Vandermeer, John, Judith Carey, Paul Gersper, Ivette Perfecto, and Peter Rosset. 1993. Cuba and the Dilemma of Modern Agriculture. Agriculture and Human Values 10 (3, Summer): 3-8.

\section{Additional Information}

Below is a list of the fact sheets in this series on Cuban Agriculture. They can be accessed by clicking on the highlighted links:

- FE479 - Cuban Agriculture Before 1959: The Political and Economic Situations

- FE480 - Cuban Agriculture Before 1959: The Social Situation

- FE481 - Transformations in Cuban Agriculture After 1959

- FE482 - Overview of Cuba's Food Rationing System

- FE483 - The Issue of Food Security in Cuba

- FE484 - Acopio: Cuba's State Procurement and Distribution Agency

- FE485 - Antecedents of the Cuban Agricultural Policies of the 1990s

- FE486 - Chronology of Cuban Reform Policies with Emphasis on Agriculture, 1993-1995

- FE487 - Cuba's Basic Units of Cooperative Production

- FE488 - Cuba's Agricultural Markets

- FE489 - Environmental Deterioration and Conservation in Cuban Agriculture

- FE490 - The Potential Correlation between Natural Disasters and Cuba's Agricultural Performance 